\title{
COULD IT HAPPEN? Global Warming, Political Coordination Failure and the Extinction of Mankind?
}

\author{
Jan-Erik Lane \\ Fellow at the Public Policy Institute, Belgrade.
}

\begin{abstract}
The governments of the countries in the world struggle with climate change and its threatening consequences for mankind chiefly by means of the UN mechanism UNFCCC. The upcoming COP23 global meeting, hosted by Fiji must outline how its three 2015 Paris COP21 objectives are to be promoted and implemented by clearly stated means or tools/tasks for international political governance and national political management. It seems now that only a massive replacement of fossil fuels and wood coal by solar and/or wind power can save mankind from the threat of global warming. How will the governments go about this formidable challenge? This paper presents a tentative estimation of what is involved with regard to the fulfilment of the GOAL II in COP21, in order to show the immensity of the political task of protecting humanity against climate change full disaster, focusing on solar power as the model example.
\end{abstract}

Key words: International governance: UNFCCC, COP23; Global warming theory (GWT), decarbonisation; COP21 Goals: I, II, III; Politics: implementation gap, game strategies, common pool regime (CPR) defection; solar power plants (Ouarzazate size).

\section{INTRODUCTION}

The UNFCCC holds a new meeting this fall in Bonn with host country Fiji - the COP23. It has to find a way forward towards the implementation of the COP21 Treaty, although there is already one defection. The islands of Fiji fear of course the sea level rise attending global warming, as there is now a set of islands becoming inhabitable in the Pacific Ocean, like e.g. Tuvalu. But the dangers involved in the global warming process concern all countries on the globe in various forms of risks, immense one in reality.

Political scientist H. Kahn showed in 1962 by Thinking of the Unthinkable that one can scientifically theorize future scenarios with the inter alia one terrible outcome, namely the elimination of the human species. Nuclear deterrent has proved effective against this result, with the possible exception of North Korea. But its leader knows that if the country hurts surrounding nations, it will suffer a terrible punishment. Global warming is different, as there is no efficient halting process in place.

Global warming theory (GWT) has come of age. It entails the possibility of a process of continuous warming of the globe until irreversibility is arrived at. Then, humanity is finished forever, as Mother Earth enters a new stage in its giant evolutionary path over hundred of millions of years. What must be done by international coordination is to set up and operate a common pool regime (CPR) that is capable to halt this climate change process in the 21rt century, and maybe reverse it. Is the UNFCCC framework this CPR? I doubt that.

\section{OUTLINE OF THE THEORY OF GLOBAL WARMING (GWT)}

One may distinguish between two parts in GWT, one much developed set of hypotheses bout the natural sciences' contribution to understanding climate change, and one poorly developed 
set of hypotheses about the difficulties in engaging in collective action, like the COP21 common pool regime (CPR) for decarbonisation.

\section{Natural sciences}

The first steps towards GWT were developed by Swedish chemist Arrhenius around 1895, suggesting that a doubling of $\mathrm{CO} 2 \mathrm{ppm}$ could result negatively in a 5 degree Celcius increase in global average temperature. It was an exaggerated calculation for 1900, but now it would not too far off the worst scenario for the 21rst century, according to UN expertise. A positive anticipation of the global warming mechanism was done by famous mathematician Joseph Fourier in the early $19^{\text {th }}$ century, arguing that with the CO2 layer the Earth would be too cold! When Stephen Schneider published Global Warming in 1989 and propagated his views in Climate Change journal, GWT started to receive wide attention, no doubt strengthened by the work of C. D. Keeling in measuring CO2 ppm globally. Moreover, techniques for viewing the CO2 layer were developed, increasing the attention to climate change. The UN reacted with creating a few bodies to look into the changes going on, one of which was the COP framework, or UNFCCC.

In the 1990s, economists jumped in besides the natural scientists, worried about the future costs of this transformation of the atmosphere. On the one hand, Kaya and associates (1998) presented a model that explained C02:s with energy and energy intensity of GDP. On the other hand, N. Stern (2007) called global warming the largest externality in human history, calling for international governance in order to stem the growth of greenhouse gases. Stern outlined a number of activities aimed at reducing $\mathrm{CO} 2$ emissions, promising also a Super Fund to channel money from rich advanced nations to poor countries and developing economies. As little has been done through the UN system of meetings and agencies up to date, Stern (2015) later asked: "What are we waiting for?"

All theories need confirmation or corroboration (Popper, 1962). When the polar ice mountains began to collapse, it seemed decisive evidence for the global warming theory. Other important test implications like glacier retreats everywhere, ocean warming and acidification as well as desertification in Africa also gave support for global warming theory. Denials of climate change appear more and more unfounded, although it is true that more of $\mathrm{CO} 2$ may benefit some fauna or environment niches.

Considering the probable damages from global warming, it is astonishing that GWT has not been fully recognized or even conceptually developed and stronger empirically corroborated.. If global warming continues unrestrained, much of Asia will be negatively affected, harbouring $50 \%$ of CO2:s now, just as Australia is on the verge of losing its coral reefs. Europe could become too cold, whereas Africa would be desert. The same holds for North and South Ameica.

Sooner or later as global warming continues, outcomes like the following arrive, here with a few examples of already occurring disasters:

- Huge land losses along the costs (Bangladesh, Vietnam);

- Too high temperatures for men and women to work outside with constant need of air conditioning increasing climate change (Middle East, South East Asia);

- Food production decline (Africa);

- Fish harvest decrease (Pacific Ocean, Atlantic, Indian Ocean);

- Droughts and starvation (Africa);

- Lack of fresh water supply (India, USA);

- Drying up of rivers, affecting electricity supply (South America); 
- Ocean acidification and species extinction (everywhere);

- Highly volatile climate with tremendous damages from flooding and storms or hurricanes and tornados (Pakistan, Sri Lanka, Bangladesh, Thailand, etc);

- Extremely violent forest fires (Portugal, Indonesia).

This list is far from complete or exhaustive. One could even mention worse outcomes, like the transformations of warm and cold currents in the oceans (Gulf Stream, North Atlantic Stream). What one may underline is that so far no known really strong negative feedback has been found that could stem global warming naturally. We have only positive feedbacks, meaning outcomes reinforce each other in the same direction. And what is even worse, global warming is reinforcing environmental degradation generally.

It is far from easy to calculate exactly how increases in greenhouse gases impact upon temperature augmentations. Take the case of CO2s, where a most complicated mathematical formula is employed: (1) $\mathrm{T}=\mathrm{Tc}+\mathrm{Tn}$, where $\mathrm{T}$ is temperature, $\mathrm{Tc}$ is the cumulative net contribution to temperature from $\mathrm{CO} 2$ and Tn the normal. "CO2" refers to all $\mathrm{CO} 2$, there is no distinction between man-made and natural CO2. But when it comes to methane, it is not known whether the tundra will melt and release enormous amounts. But methane does not stay in the atmosphere long, like CO2s. For the other greenhouse gases, there is no similar calculation as for the CO2s: If humans could eat less meat from cows, it would mean a great improvement, as more than a billion cows emit methane. Food from chicken should replace beef meat and burgers. The general formula reads: (2) dT $=\lambda^{*} \mathrm{dF}$, where 'dT' is the change in the Earth's average surface temperature, ' $\lambda$ ' is the climate sensitivity, usually with degrees Celsius per Watts per square meter $\left({ }^{\circ} \mathrm{C} /[\mathrm{W} / \mathrm{m} 2]\right)$, and ' $\mathrm{dF}$ ' is the radiative forcing.

\section{Political sciences}

The part of GWT analyzing the coordination efforts within the UNFCCC as well as the different country responses to climate change is far less developed than the natural sciences' part. One finds practically nothing in the UNFCCC documents about the principal problems in large scale international governance, like e.g. defection. One may speak of two currents of social science theory that are highly relevant for GWT:

i. Implementation theory: In the discipline of public administration and policy-making, some ideas about the so-called "implementation gap" - Wildavsky's hiatus - are highly relevant to the COP21 project (Pressman and Wildavsky, 1973, 1984). The COP21 has three main objectives: halt CO2 increases by 2018-2020 (GOAL I), decrease CO2 emissions considerable by 2030 (GOAL II) and achieve full decarbonistion by 2070-80 (GOAL III).

But how are they to be implemented? No one knows, because COP21 has neglected what will happen after the major policy decision. The COP21 project outlines many years of policy implementation to reach decarbonisation, but which are the policy tools?

ii. Game theory: A common pool regime, or CPR is vulnerable to the strategy of reneging, as analysed theoretically in the discipline of game theory. The relevant game for the CPR is the PD game, where the sub game perfect Nash equilibrium is defection in a finite version of this game (Dutta, 1999). This is not recognized by Elinor Ostrom (1990) in her too optimistic view about the viability of CPR:s. It is definitely not the case that Ostrom has overcome Hobbes, as one commentator naively declared when she was awarded both the Nobel prize and the Johan Skytte prize (Rothstein' website 2014). The COP21 project houses lots of reneging opportunities of various sorts, which will become clear as this CPR project moves forward. One major partner has already defected, which may 
trigger other governments to renege. The only way to control defection in this global CPR is to employ selective incentives, which is what the planned Super Fund could offer, if at all workable.

\section{THE PROBLEMATIC OF GLOBAL WARMING: ANTHROPOGENIC NEED OF ENERGY}

To have a firm foundation for understanding the immense increase in $\mathrm{CO} 2$ emissions the last two decades, we resort to the Kaya model, linking CO2:s with energy and affluence (Kaya and Yokoburi, 1997). In theories of climate change, the focus is upon so-called anthropogenic causes of global warming through the release of greenhouse gases (GHG). To halt the growth of the GHG:s, of which C02:s make up about 70 per cent, one must theorize the increase in CO2:s over time (longitudinally) and its variation among countries (cross-sectionally). As a matter of fact, C02:s have very strong mundane conditions in human needs and social system prerequisites. Besides the breading of living species, like Homo sapiens for instance, energy consumption plays a major role. As energy is the capacity to do work, it is absolutely vital for the economy in a wide sense, covering both the official and the unofficial sides of the economic system of a country.Thus, we have this equation format:

(E1) Multiple Regression: $Y=a+b_{1} X_{1}+b_{2} X_{2}+b_{3} X_{3}+\ldots+b_{t} X_{t}+u$

Thus, using the Kaya model for empirical research on global warming, the following anthropogenic conditions would affect positively carbon emissions: (E2) CO2:s = F(GDP/capita, Population, Energy intensity, Carbon intensity), in a stochastic form with a residual variance, all to be estimated on data from some 59 countries. I make an empirical estimation of this probabilistic Kaya model - the cross-sectional test for 2014: (E3) k1=0,68, $\mathrm{k} 2=0,85, \mathrm{k} 3=0,95, \mathrm{k} 4=0,25$; R2=0,895. Note: LN CO2 = k1*LN (GDP/Capita) $+\mathrm{k} 2 *$ (dummy for Energy Intensity) $+\mathrm{k} 3 *$ (LN Population) $+\mathrm{k} 4 *$ (dummy for Fossil Fuels/all) Dummy for fossils 1 if more than $80 \%$ fossil fuels; $\mathrm{k} 4$ not significantly proven to be non-zero, all others are. $(\mathrm{N}=$ 59).

The findings show that total CO2:s go with larger total GDP. First, we see that $\mathrm{CO} 2$ emissions are closely connected with energy consumption, globally speaking. And the projections for future energy augmentation in the $21^{\text {st }}$ century are enormous (EIA, BP, IEA). Figure 1 shows how things have developed since 1990. 
FIGURE 1. Global GDP-C02 link: $y=0,4092 x+25,03, R^{2}=0,987(N=26)$

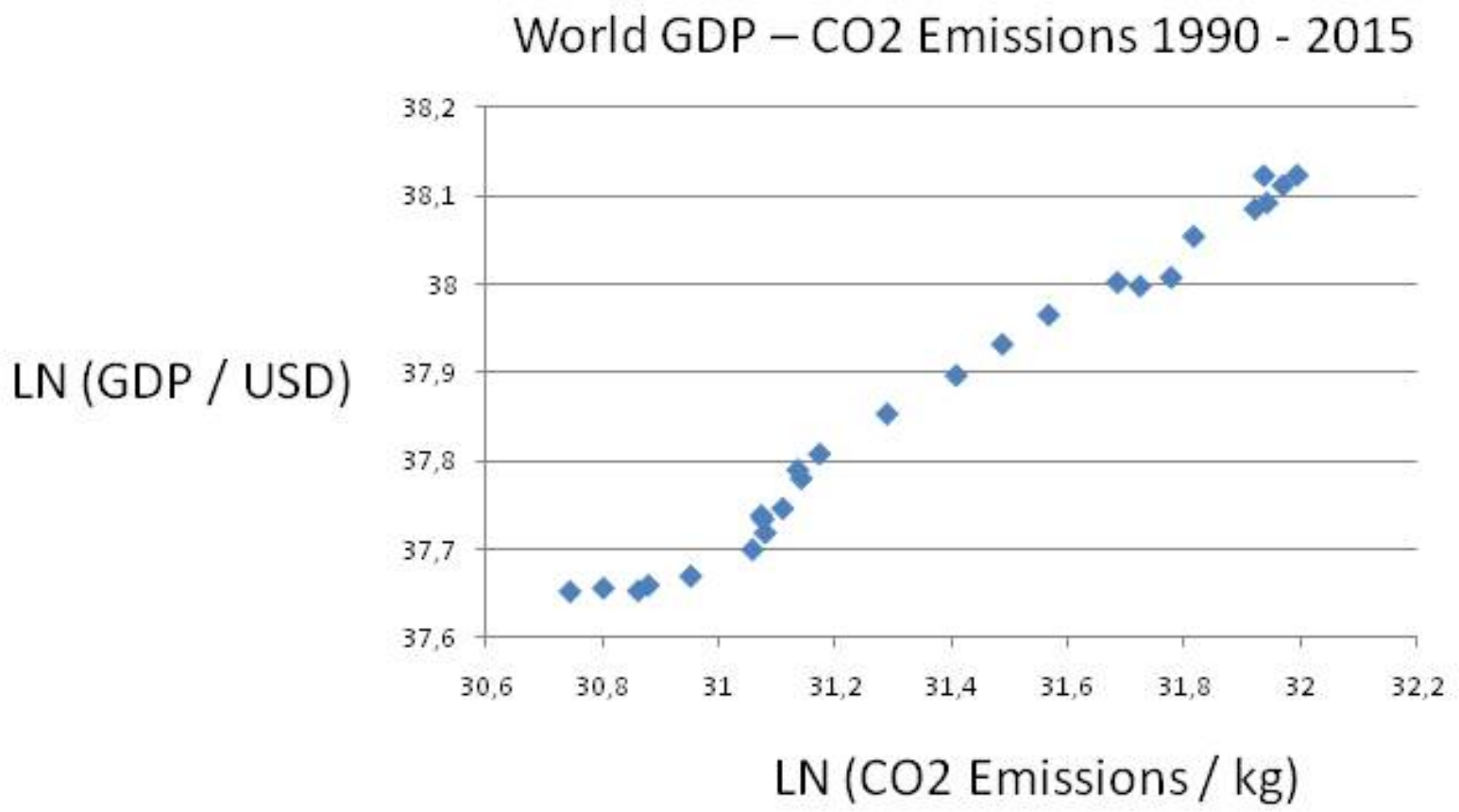

To make the dilemma of energy versus emissions even worse, we show in Figure 2 that GDP increase with the augmentation of energy per capita. Decarbonisation is the promise to undo these dismal links by making GDP and energy consumption rely upon carbon neutral energy resources, like modern renewables and atomic energy.

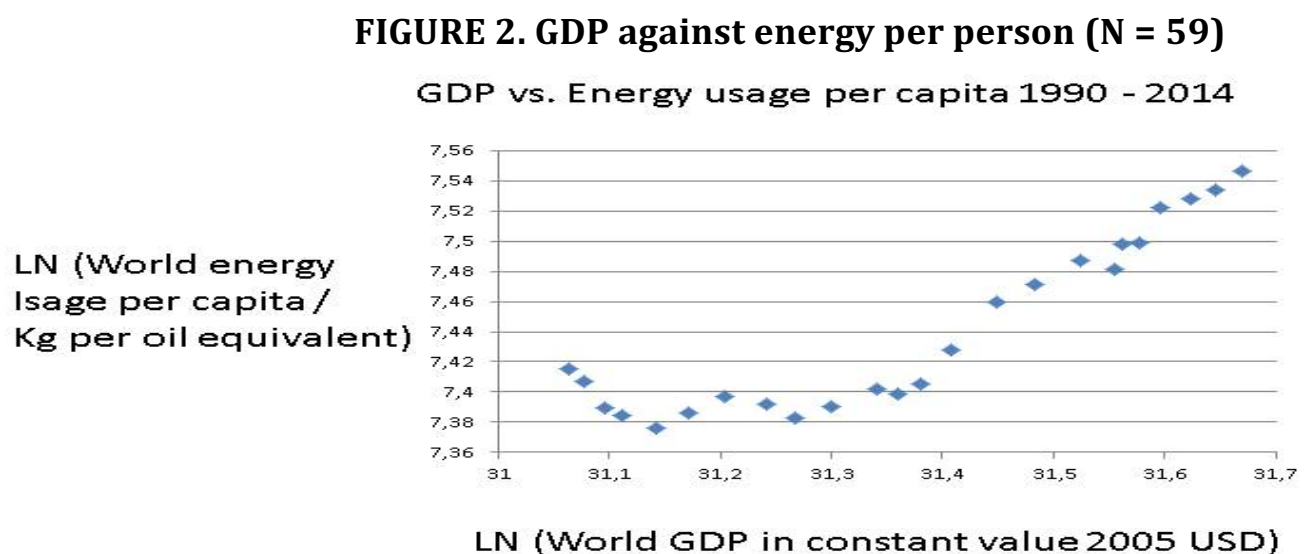

Thus, we arrive at the energy-emissions conundrum: GDP growth being unstoppable requires massive amounts of energy that results in GHC:s or C02:s. The only way out of this dilemma is that renewables become so large and effective in a short period of time decarbonisation becomes feasible or likely, not merely desirable. All forms of energy be measured, and these measures are translatable into each other - a major scientific achievement. One may employ some standard sources on energy consumption and what is immediately obvious is the immensely huge numbers involved - see Table 1. 


$\begin{array}{lll}\text { TABLE 1. Energy consumption } & 2015 & \text { (Million Tons of oil equ } \\ & & \\ \text { Fossil fuels } & 11306,4 & 86,0 \\ \text { Oil } & 4331,3 & 32,9 \\ \text { Natural Gas } & 3135,2 & 23,8 \\ \text { Coal } & 3839,9 & 29,2 \\ \text { Renewables } & 1257,8 & 9,6 \\ \text { Hydroelectric } & 892,9 & 6,8 \\ \text { Others } & 364,9 & 2,8 \\ \text { Nuclear power } & 583,1 & 4,4 \\ \text { Total } & 13147,3 & 100,0\end{array}$

\section{Source: BP Statistical Review of World Energy 2016}

It is true that a lot is happening with energy and emissions, but one tends to report only the positive news about coal reduction, more efficiency in energy consumption, new solar and wind plants. Sad to say, one bypasses the constantly increasing need for energy, the augmentation of air transportation, more cars and bigger engines, and first and foremost more human beings! The COP21 call for decarbonisation entails a sharp reduction of fossil fuels up until 2030 in order to stabilize climate change, involving a 30-40 decrease in CO2 emissions, measured against the 2005 level of emissions.

\section{SOLAR POWER PLANTS: GLOBAL ESTIMATION OF GOVERNMENT OBLIGATIONS}

Let us examine what this hoped for reduction of fossil fuels implies for the augmentation of renewable energy consumption, here solar power. The use of atomic power is highly contested, some countries closing reactors while others construct new and hopefully safer ones. I here bypass wind power and thermal power for the sake of simplicity in calculations. But wind power is highly relevant and would substitute for solar power. Geo-thermal power is country specific. Actually, every country has its specificities when it comes to energy resources and energy consumption.

Consider now Table 2, using the giant solar power station in Morocco as the benchmark, it asks: How many would be needed to replace the energy cut in fossil fuels and maintain the same energy amount, for a few selected countries with very big $\mathrm{CO} 2$ emissions? 
Table 2. Number of Ouarzazate type solar plants for decarbonisation 2030

\begin{tabular}{|l|l|l|l|}
\hline Nation & $\begin{array}{l}\text { Co2 reduction } \\
\text { pledge / } \\
\text { \% of 2005 } \\
\text { emissions }\end{array}$ & $\begin{array}{l}\text { Number of } \\
\text { gigantic solar } \\
\text { plants needed } \\
\text { (Ouarzazate) }\end{array}$ & $\begin{array}{l}\text { Gigantic plants } \\
\text { needed for 40 \% } \\
\text { reduction }\end{array}$ \\
\hline United States & $26-28^{1}$ & 2170 & 3100 \\
\hline China & none ${ }^{2}$ & 0 & 3300 \\
\hline EU28 & $41-42$ & 2300 & 2200 \\
\hline India & none ${ }^{2}$ & 0 & 1700 \\
\hline Japan & 26 & 460 & 700 \\
\hline Brazil & 37 & 170 & 190 \\
\hline Indonesia & 29 & 120 & 170 \\
\hline Canada & 30 & 230 & 190 \\
\hline Mexico & 25 & 120 & 940 \\
\hline Australia & $26-28$ & 130 & 1900 \\
\hline Russia & none & 0 & N/A \\
\hline World & N/A & As & 190 \\
\hline
\end{tabular}

Note: Average of 250 - 300 days of sunshine used for all entries except Australia, Indonesia, and Mexico, where 300 - 350 was used.

Sources: Paris 2015:

Tracking country climate pledges. Carbon Brief, https://www.carbonbrief.org/paris-2015tracking-country-climate-pledges; EDGAR v 4.3.2, European Commission, Joint Research Centre (JRC)/PBL Netherlands Environmental Assessment Agency. Emission Database for Global Atmospheric Research (EDGAR), release version 4.3.2. http://edgar.jrc.ec.europe.eu, 2016 forthcoming; CO2 Emission Reduction With Solar

http://www.solarmango.com/in/tools/solar-carbon-emission-reduction

Allow me to doubt that the UNFCCC or the COP21-22 are aware of the immensity of the task of implementing GOAL II until 2030. Several countries will find even GOAL I hard to fulfill! The COP23 must urgently clarify how such enormous amounts of solar power can be achieved by 2030 - plan or spontaneous order? Such an enormous energy transformation can only be made by the use of market initiatives and incentives (Barry, 1982; Hayek, 1991), but governments

\footnotetext{
${ }^{1}$ America pulled out from the deal in June 2017

${ }^{2}$ China and India has only made pledges in terms of CO2 emissions per GDP, not absolute targets

${ }^{3}$ Russia made pledge of 25 - 30 \% compared to 1990 levels, but this has already been met due to a shrinking economy

${ }^{4}$ Unclear sum of all countries pledges, several nations have interval in their commitments
} 
must put down the fundamental rules of the game for the promotion of renewables: subsidies, charges or taxes? The best would be common international regulation, as otherwise each country may chose its special way (Ramesh, 2015).

\section{DISMAL SCIENCE: NO PLACE FOR GLOBAL UTOPIANISM}

What is at stake for most people who understand the risks with climate change is not the desirability of decarbonisation in some form or another. They crux of the matter is feasibility: How to promote decarbonisation so that real life results occur? The real obstacles for any decarbonisation project stem from the logic of collective action, if we stick to the social sciences, as ethically neutral and truthfully objective - the Mathusian ideal. The energyemissions conundrum is probably unresolvable until fusion power arrives! And it may not arrive in time for a global catastrophe to be avoided, as the Earth turns slowly inhabitable for humans. At the UNFCCC, there is an ambition to link GWT with other ideas, like sustainability, poverty reduction and income and wealth redistribution (Sachs, 2015). But it only creates confusion and spread conflict, when action is needed. Is the Super Fund feasible at all?

\section{SOLAR POWER TRANSITION: A FEW POLITY EXAMPLES}

Even when one examines countries that are not among the 5-10 worst polluters, one is struck by the immense need for solar power plants. Consider below a few very important polities with high strung plans for catching-up with the advanced economies of the world (Barro, 1991).

Table 3. Number of Ouarzazate type solar plants for decarbonisation 2030

\begin{tabular}{|l|l|l|l|}
\hline Nation & $\begin{array}{l}\text { Co2 reduction } \\
\text { pledge / } \\
\text { \% of 2005 } \\
\text { emissions }\end{array}$ & $\begin{array}{l}\text { Number of } \\
\text { gigantic solar } \\
\text { plants needed } \\
\text { (Ouarzazate) }\end{array}$ & $\begin{array}{l}\text { Gigantic plants } \\
\text { needed for 40 \% } \\
\text { reduction }\end{array}$ \\
\hline Saudi Arabia & none & 0 & 150 \\
\hline Iran & $4-12^{6}$ & 22 & 220 \\
\hline Kazakhstan & none & 0 & 90 \\
\hline Turkey & 21 & 60 & 120 \\
\hline
\end{tabular}

Note: Average of 300 - 350 days of sunshine per year was use.

Sources: Paris 2015:

Tracking country climate pledges. Carbon Brief, https://www.carbonbrief.org/paris-2015tracking-country-climate-pledges; EDGAR v 4.3.2, European Commission, Joint Research Centre (JRC)/PBL Netherlands Environmental Assessment Agency. Emission Database for Global Atmospheric Research (EDGAR), release version 4.3.2. http://edgar.jrc.ec.europe.eu, 2016 forthcoming; CO2 Emission Reduction With Solar http://www.solarmango.com/in/tools/solar-carbon-emission-reduction

\footnotetext{
${ }^{5}$ No concrete pledge

${ }^{6}$ Lower limit unconditional, upper limit dependent on financial support

7 Pledge is higher than current level
} 
Very much depends upon the rationality of politics in these polities. Can Saudi Arabia, Iran and Kazakhstan be convinced to reduce the burning of fossil fuels and invest massively in solar power plants, although a costly alternative. Turkey suffers from systemic political instability, which may hamper the acceptance of global political rationality to save humanity.

Or turn to the Americas, with a few giant polities, also striving for economic growth! Canada would have to concentrate upon solar plants instead of oil sands and huge gas pipelines southward. Mexico could turn away from his total oil reliance and benefit from all the sun coming in daily. Brazilian politicians hope for a large exploitation of hydro power in the Amazons (like the huge dam in Bela Horizonte), but it will destroy the rain forest. Better to build solar power plants all over its giant territory, as water may decline in the Andes. Technologically advanced Chile with its political stability should be able to handle this energy transition.

Table 4. Number of Ouarzazate type solar plants for decarbonisation 2030

\begin{tabular}{|l|l|l|l|}
\hline Nation & $\begin{array}{l}\text { Co2 reduction } \\
\text { pledge / } \\
\text { \% of 2005 } \\
\text { emissions }\end{array}$ & $\begin{array}{l}\text { Number of } \\
\text { gigantic solar } \\
\text { plants needed } \\
\text { (Ouarzazate) }\end{array}$ & $\begin{array}{l}\text { Gigantic plants } \\
\text { needed for 40 \% } \\
\text { reduction }\end{array}$ \\
\hline Canada & 30 & 230 & 300 \\
\hline Mexico & $25-40^{8}$ & 140 & 220 \\
\hline Brazil & 43 & 210 & 190 \\
\hline Chile & 35 & 30 & 32 \\
\hline
\end{tabular}

Note: Average of 250 - 300 days of sunshine per year was used.

Sources: Paris 2015:

Tracking country climate pledges. Carbon Brief, https://www.carbonbrief.org/paris-2015tracking-country-climate-pledges; EDGAR v 4.3.2, European Commission, Joint Research Centre (JRC)/PBL Netherlands Environmental Assessment Agency. Emission Database for Global Atmospheric Research (EDGAR), release version 4.3.2. http://edgar.jrc.ec.europe.eu, 2016 forthcoming; CO2 Emission Reduction With Solar

http://www.solarmango.com/in/tools/solar-carbon-emission-reduction

\section{CONCLUSION: INSUFFICIENCY THESIS}

International political coordination in the entire UNFCCC runs with a basic insufficiency, making it too weak to respond to the climate change challenge that could bring about a worst case scenario for mankind. Scholars have shown that the UN climate decision-making is highly manipulated by self-interests from the major powers (Conca, 2015; Vogler, 2016). The ideas of using climate change policy-making to solve other problems like poverty, global redistribution of wealth and stopping general environment degradation make matters just more complicated, resulting in massive transaction costs and likely policy failures.

The likelihood of disaster is on the increase, which is why I have written many articles on climate change and intergovernmental coordination. It is not probable that solar energy can

\footnotetext{
${ }^{8}$ Lower limit unconditional, upper limit contingent on global deal
} 
both replace lots of fossil fuel and wood coal energy as well as provide for the planned strong increased demand for energy - see Figure 3.

FIGURE 3. Future energy demand (IEA projection)

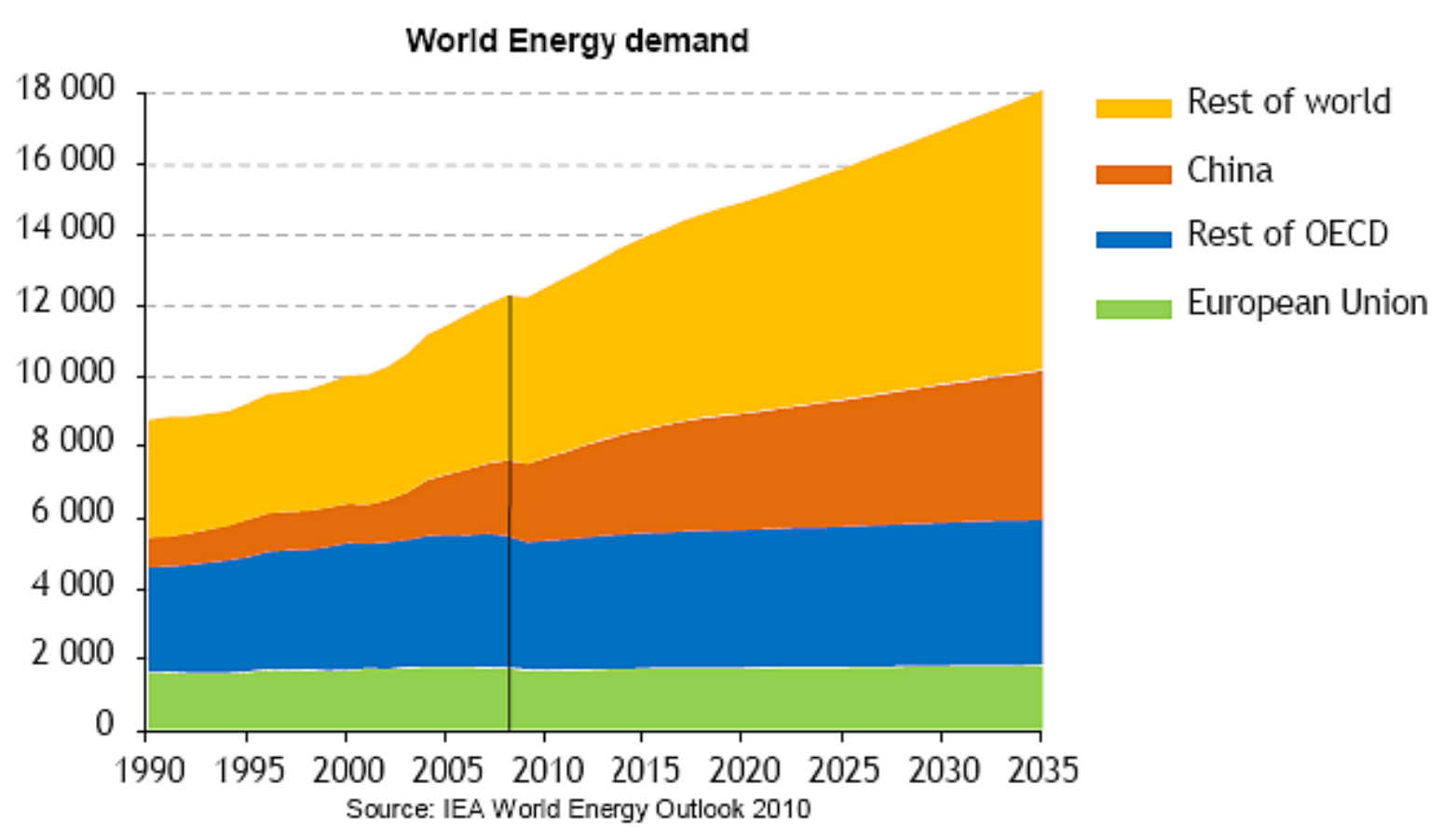

More of energy in Figure 3 leads to $\mathrm{CO} 2$ emissions, as the demand for solar power energy will surely outpace the supply of solar power plants, according to the calculations in Table 2 . Something has to give. I much fear it will be climate stability rather socio-economic development or economic growth..

\section{References}

\section{GDP sources:}

World Bank national accounts data - data.worldbank.org

OECD National Accounts data files

\section{GHG and energy sources:}

World Resources Institute CAIT Climate Data Explorer - cait.wri.org EU Joint Research Centre Emission Database for Global Atmospheric Research - http://edgar.jrc.ec.europa.eu/overview.php UN Framework Convention on Climate Change http://unfccc.int/ghg_data/ghg_data_unfccc/time_series_annex_i/items/3814.php International Energy Agency. Paris.

Energy Information Administration. Washington, DC.

BP Energy Outlook 2016.

EU Emissions Database for Global Research EDGAR, http://edgar.jrc.ec.europa.eu/

World Bank Data Indicators, data.worldbank.org

British Petroleum Statistical Review of World Energy 2016

\section{Literature}

"Arrhenius, Svante August" in Chambers's Encyclopædia. London: George Newnes, 1961, Vol. 1. 
Barry, B. (1982) “The Tradition of Spontaneous Order”, in Literature of Liberty. Vol. V, No. 2, pp. 7-58. Arlington, VA: Institute for Humane Studies.

Conka, K. (2015) Un Unfinished Foundation. The United Nations and Global Environmental Governance. Oxford: OUP.

Dutta, P.L. (1999) Strategies and games. Cambridge, MA: MIT Press.

Hayek, F.A. (1991) The Fatal Conceit: The Errors of Socialism. Chicago: The University of Chicago Press.

Kahn, H. (1962) Thinking about the Unthinkable. Far Hills, NJ: Horizon Press.

Kaya, Y., and Yokoburi, K. (1997) Environment, energy, and economy: Strategies for sustainability. Tokyo: United Nations University Press.

Ostrom, E. (1990) Governing the Commons. Cambridge: Cambridge U.P.

Popper, K.R. (1962) Conjectures and Refutations. London: Routledge

Pressman, J, and Wildavsky, A. $(1973,1984)$ Implementation. Berkeley: University of Cal Press.

Ramesh, J. (2015) Green Signals: Ecology, Growth and Democracy in India (2015). Oxford : Oxford University Press.

Sachs, J.D. (2015) The Age of Sustainable Development. New York: Columbia University Press.

Stern, N. (2007) The Economics of Climate Change. Oxford: OUP.

Stern, N. (2015) What are we waiting for? Cambridge, MA: MIT Press.

Vogler, J. (2016) Climate Change in World Politics. Basingstoke: MacmillanPalgrave 